\title{
Pathways to music torture
}

Les voies de la musique comme torture

\section{Morag Josephine Grant}

\section{(2) OpenEdition}

Journals

Édition électronique

URL : http://journals.openedition.org/transposition/494

DOI : 10.4000/transposition.494

ISSN : 2110-6134

\section{Éditeur}

CRAL - Centre de recherche sur les arts et le langage

\section{Référence électronique}

Morag Josephine Grant, «Pathways to music torture », Transposition [En ligne], 4 | 2014, mis en ligne le 15 juillet 2014, consulté le 10 décembre 2020. URL : http://journals.openedition.org/transposition/494 ; DOI : https://doi.org/10.4000/transposition.494

Ce document a été généré automatiquement le 10 décembre 2020.

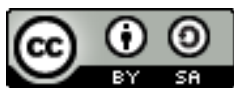

La revue Transposition est mise à disposition selon les termes de la Licence Creative Commons Attribution - Partage dans les Mêmes Conditions 4.0 International. 


\title{
Pathways to music torture
}

\author{
Les voies de la musique comme torture
}

Morag Josephine Grant

\section{NOTE DE L'AUTEUR}

I gratefully acknowledge the research assistance of Mareike Jacobs, Anna Papaeti and Stephanie Leder in collating some of the sources I draw on here.

1 In the history of torture, the period since the Second World War is in many ways marked by contradictions. On the one hand, the atrocities of the 1930s and 1940s precipitated moves towards an international legal framework for preventing and punishing torture: this was a further step in a trend away from the use of torture that reaches back at least as far as the eighteenth century, and which in the period since 1945 was closely related to the increasingly influential role of civil society. On the other hand, the use of torture has persisted and, in some cases, reemerged, often in apparently "new" forms that seek to mask the very fact that we are dealing here with torture in a strict sense at all. It is in this context in particular that the use of music as an instrument of torture has come into focus - specifically, as employed by US security forces in the so-called "War on Terror". ${ }^{1}$ As several studies and investigations have shown, this and other torture practices used alongside it can easily be placed in a longer history of developments in military and security strategy in the 1940s-1950s, particularly with regard to so-called "sensory deprivation" techniques, which I will discuss in more detail below. This, however, is only one of many pathways to the extensive use of music as a form of torture and cruel, inhuman and degrading punishment, especially since this can take many forms (it is by no means limited to subjecting prisoners to constant loud music played through loudspeakers or headphones) and has a much longer and broader history than many accounts suggest. Studies of music in National Socialist concentration camps have demonstrated the often systematic use of what Juliane Brauer terms musical violence, ${ }^{2}$ to take just the most well-researched example. The use of certain forms of forced singing not only to humiliate prisoners of war, political opponents and others, but also as a 
particularly perfidious form of self-inflicted violence, has been reported in this context and many other more recent ones besides. But the history is longer still, and is just one component of a relationship between music and punishment, including the severest forms of punishment, that stretches back almost certainly as far as documentation of any sort exists. ${ }^{3}$ Closer analysis of the circumstances and apparent functions of music in all these cases reveals the need for a broader understanding of what might constitute music torture, and also for research into this topic to be placed against a broader historical background.

2 In this essay, I will attempt to trace some of these pathways to music torture both synchronically and diachronically. They will lead us into considerations of such topics as the role of music in the military, developments in security strategy and technology since the late nineteenth century, the function of music in social and political movements, and the relationship between music and humiliation. Sometimes causal connections will become apparent; in many cases, however, we may be left feeling that practices of music torture arise spontaneously, even naturally. These pathways - sometimes converging, sometimes running in parallel - thus bring into focus important aspects of the social structure of torture, the social functions of music, and a relationship that becomes more logical the longer we observe it. Nevertheless, many of the observations given below retain the character of hypotheses. In this sense, the pathways outlined are indications of where future research might need to go, as well.

\section{Music as Torture}

3 Most forms of torture do not need much explanation for us to understand why they are torture: being beaten repeatedly on the soles of ones' feet, having electric shocks administered to one's genitals, having healthy teeth pulled without anaesthetic, or being stretched beyond the body's natural limits on a rack - these are tortures we can immediately comprehend; even thinking of them makes us wince. Music torture is different. There are certainly a number of obvious reasons why music is used in the context of torture, some of which will be discussed in more detail below: to cover the sound of screams, to further humiliate and degrade prisoners. That such uses of music could themselves impact on prisoners in a manner that is in any way comparable to the types of torture just mentioned - that music can be part of the main event and not merely an accompaniment - is however by no means self-explanatory. This is perhaps one of its appeals to the torturers.

4 That we know of music's efficacy as an instrument of torture is due in large part to testimonies from survivors. How people react to music in the context of torture is as individual as with any other type of torture; thus, the use of music to torture should never be viewed as the lesser of many potential evils simply because not all survivors give it the same weight. Testimonies provided by survivors of torture from Uruguay in the 1970s provide a lesser-known but very telling example of this. The context was a period of military rule lasting from 1973 to 1985, and which was marked by widespread and grave human rights violations including arbitrary detention, torture, and disappearances. A set of six signed affidavits made before a notary public in Mexico by political refugees from Uruguay, statements translated and published by Amnesty International, describe various methods of torture inflicted at a number of locations and by a number of security service and military divisions. The most frequently recurring types of torture are "standing" 
(being forced to stand for anything up to several days), hooding, the technique known as "submarine" (now more generally known by the American term, "waterboarding") and the application of electric shocks, as well as hitting and kicking. Two of the survivors mention that radio and/or records were played at high volume at some locations. One of these two survivors then goes on to mention what happens when he was transferred to what he terms a concentration camp:

We were subjected to the following tortures:

The noise of MUSIC played. Day and night very loudly.

"SUBMARINE". They placed a plastic or muslin bag over our heads and tied it round the neck. We suffocated through having no air or being submerged in water or excrement.

"STANDING" (Planton). ${ }^{4}$ Standing with our legs and arms wide apart, for hours, being hit on the legs, the kidneys and the stomach.

ELECTRIC SHOCKS. A rubber truncheon of American manufacture, about 60 centimetres long, with an aluminium stud, through which the current is transmitted.

SUSPENSION. By the thumbs or arms, for hours or days.

PSYCHOLOGICAL TORTURE. Very loud music. The detainees who were in a particularly poor state of health were placed near where tortures were being carried out, so that they might know what would happen to them. ${ }^{5}$

Striking in this excerpt is not only that constant loud music is the first of the torture practices listed, but that it is mentioned twice, the second time as the main method of psychological torture. None of the other six statements mention a similar use of music, though this could be because the practice may not have been used at all facilities. The use of music as a method of psychological torture is, however, mentioned in another source from Uruguay, namely the testimony given by a survivor to the UN Human Rights Council and published in its conclusions to the complaint he brought against the state of Uruguay; it relates to a period of torture in April 1976:

The method chiefly used in my case was mental torture. For many hours at a time I could hear piercing shrieks which appeared to come (and perhaps did come) from an interrogation under torture; the shrieks were accompanied by loud noises and by music played at a very high volume. I was repeatedly threatened with torture and on several occasions I was abruptly transferred to other places, amid threats and ill-treatment. ${ }^{6}$

Both these descriptions (the second more than the former) connect psychological or mental torture chiefly to the sound of music, screams, and loud noises. Neither gives information on the music used, nor a definitive answer to the question of how the music affected them, particularly as compared to other sounds and to the noise of screams presumably coming from (or supposed to come from) other victims (it is not outside the bounds of possibility that the two men concerned knew that loud music is often used to cover the sounds of torture). ${ }^{7}$ Other sources, particularly in statements from former prisoners of US detention camps at Baghram, Guantánamo Bay and others, go into more detail on the effects of constant loud music. ${ }^{8}$ Testimonies gathered from survivors of torture in Greece only a couple of years before the example cited from Uruguay also describe the impact of music and noise during interrogations and beatings but also between them. ${ }^{9}$ The similarity of the historical circumstances and the techniques used in these and other cases will be a starting point for many of the pathways discussed below.

7 Before moving on to these, however, a few words are necessary on the framework behind this discussion, particularly as it concerns what is meant here by "music", but also what is meant by torture. In this article, I use terms such as "music," "musical," and "musical 
practice," amongst others, in a broad sense which I feel is necessary both to tease out the multifarious social significances of the practices concerned but also to get away from a focus on music as a specifically (and even exclusively) sonic phenomenon of relative structural complexity. The result of this is that in this discussion, "music" may cover the whole gamut of human musical expression, from the rhymes chanted by children at play (see Pathway 4) through to music in ceremonial contexts and works of art, but especially in the form of the adjective "musical" - can also be extended to help us interpret other forms of communication and expression that demonstrate musical qualities (see particularly the discussion of the interrogation scene from the film Songs of War, below, Pathway 5)..$^{10}$ As a social musicologist, I implicitly view music as integral to and constitutive of human social relations; musical activities and practices imply relationships between human beings, help express these but also, in many cases, form and consolidate these relationships. ${ }^{11}$ In addition, several of the practices and phenomena that I describe in this essay are necessarily not torture in the strict sense, though many of these certainly are instances of what the language of human rights calls cruel, inhuman and degrading treatment or punishment (CID treatment). In human rights law, torture is grouped together with and prohibited alongside CID treatment in recognition of the connections; human rights advocates are increasingly pointing to the necessity of preventing CID treatment as a necessary prerequisite for preventing torture. ${ }^{12}$ The very widespread practice of forcing prisoners to sing demonstrates neatly why, in the specific case of music torture as well, it is necessary to extend the discussion beyond torture proper. Forced singing has only rarely been the topic of musicological investigations and other writings into what is called music torture, which have tended to focus on more technologised practices such as subjecting people to constant music through loudspeakers (similarly, the approach to this topic at all is often highly technologised or even aestheticised). Not all examples of forced singing occur in contexts and reach a severity that can be classed as torture, though they still constitute a violation of prisoners' rights. ${ }^{13}$ But like many of the practices I discuss, music bears a potential in conjunction with or as a method of torture which can only be understood through looking at other phenomena, practices, and traditions. The discussion below, therefore, should by no means be understood as an attempt to dilute definitions of torture generally or music torture specifically.

\section{Pathways to music torture}

8 The pathways outlined below indicate on the one hand that the historical relationship between music and torture is long, on the other that there are numerous social, political, legal and technological reasons why the use of music in connection with torture may have increased over the course of the twentieth century. Due to the complexities involved, these pathways are not given in any sort of chronological order. We will start, however, with a pathway highly relevant for the most famous of the recent cases.

\section{The "sensory deprivation" pathway}

In the brief hiatus between the end of the Second World War and the beginning of the Cold War, a committee set up by the newly founded United Nations began to draft a declaration aimed at preventing further wars and armed struggles not least by promoting 
and protecting what came to be seen as universal rights of all human beings. ${ }^{14}$ The result was the Universal Declaration of Human Rights (UDHR), which was passed by the General Assembly of the UN on 10 December 1948, one day after the Convention on the Prevention and Punishment of the Crime of Genocide. Though itself not legally binding, the UDHR became the cornerstone of a still-expanding universe of international treaties and institutional structures aimed at delineating and overseeing the protection of the rights laid out in that document. Within this complex field of interacting and mutually conditional human rights, certain rights are viewed, in the language of jurists, as nonderogable: that is, they apply absolutely and in all situations. These include the right to life, the prohibition of slavery, and the prohibition of torture and cruel, inhuman, and degrading treatment or punishment.

The absolute prohibition of torture found in the UDHR and in the conventions which build on it, not least the Convention Against Torture (CAT) of 1984, can be seen as the reiteration of a principle already accepted (in principle, at least) in many countries no later than the nineteenth century. Whether this principle had led to a real decline in incidences of torture, or merely pushed them underground, is however a moot point. ${ }^{15} \mathrm{At}$ the very least, though, the prohibition of torture in the UDHR can be seen as a clear sign of a general moral consensus on torture as cruel and inhuman. And somewhat ironically, the moral and legal power of such a consensus is evidenced even in the fact of attempts to sidestep the prohibition, including by experimenting with forms of torture which for a long time were not considered as such. Similarly, what is sometimes termed "no touch torture", by putting a crucial distance (from the point of view of the torturers) between them and the victim, can be seen as a further way to facilitate what was clearly an illegal and highly immoral act.

11 This, then, is one of the starting points for the development of new methods of torture in the 1950s and 1960s that necessitated no direct physical violence on the part of the torturer and yet produced exactly the kind of destruction of the subjectivity of the victim that is characteristic of torture generally. The development of these techniques is in every way related to the Cold War, first as a reaction to the apparent use of brainwashing in the Soviet Union and in China, and then in the form of training offered to dictatorships and military regimes seen to be combating socialist or communist elements in their own countries (which is one reason why similar methods emerge in different countries at broadly the same time).${ }^{16}$ As Alfred McCoy has explored in detail, the starting point was an extensive programme of research carried out by psychologists in the USA, Canada and Great Britain, in some cases apparently with covert funding from the CIA, which examined the impact of what was variously termed sensory deprivation or perceptive isolation. In experiments ostensibly geared at understanding a range of psychiatric disorders including schizophrenia, participants in the experiments were subjected to a range of measures aimed at ensuring they could have no meaningful sensorial interaction with their environment through sight, touch, or hearing. ${ }^{17}$ Measures relating to the lastmentioned could take one of two approaches: enclosing the subject in an anechoic chamber, or alternatively using a constant noise of a frequency structure and amplitude designed to mask any other noises. The former technique is taken to have been adopted from experiments carried out in the Soviet Union which may have been the impetus for the experiments carried out by the US government and its allies. Given the technical difficulties but also the limitations of anechoic chambers, it is understandable why the latter measure would prove to be more useful (anechoic chambers, as John Cage famously 
described, do not actually prevent audition of any noise, since in this environment the subject can hear the noise of bodily processes normally not audible in any other situation). ${ }^{18}$

It is now well-known that practices clearly related to these experiments were used extensively not only by the US and British governments, but through them - in the form of training programmes, but also by simple example - in many other countries as well. Long before similar techniques came to international attention in connection with the "War On Terror", they had triggered public controversy and legal campaigns when used against at least fourteen prisoners in Northern Ireland. The so-called "five techniques" as they came to be called in connection with this case, included standing, hooding, sleep deprivation, withholding of food and drink, and subjection to noise. ${ }^{19}$ Responding to that controversy in the form of an inquiry overseen by three peers, it is notable (and in retrospect, astounding) that the majority decision adopted by two of the three referred to the techniques' extensive use across a whole host of former British colonies from the 1950s onwards as justification for their continued, if limited, use. ${ }^{20}$ When the case came before the European Court of Human Rights, the Court decided that the measures did not constitute torture in the strict sense, but certainly were a form of inhuman and degrading treatment, thus also representing a violation of the European Convention on Human Rights. ${ }^{21}$ More than twenty years later, the UN Committee Against Torture came to a different conclusion, stating in the context of the regular reporting foreseen for parties to the Convention, in this case reports from Israel, that methods including "(1) restraining in very painful conditions, (2) hooding under special conditions, (3) sounding of loud music for prolonged periods, (4) sleep deprivation for prolonged periods, (5) threats, including death threats, (6) violent shaking, and (7) using cold air to chill [...] constitute torture as defined in article 1 of the Convention [Against Torture]", particularly "where such methods of interrogation are used in combination, which appears to be the standard case". ${ }^{22}$

The Israeli case specifically mentions the use of loud music, but as the Uruguayan example cited earlier shows, this was by no means a recent development. And while the examples discussed above refer to only one of the two basic forms of music torture subjection to music rather than being forced to perform - the very widespread use of various forms of forced singing, which will come into more focus in the discussion of other pathways, can also be understood within this nexus, since methods of sensory deprivation were often used in conjunction with stress positions, the common denominator being that all are practices of so-called "no-touch torture".

These are only some of very many reports of loud music used in the context of torture that can be found from the 1970s onwards. Whether or not there was an upsurge in such specifically musical techniques at exactly this point is difficult to tell, not least since most of the easily available sources for this research stem from institutions and organisations most notably Amnesty International - which began working extensively on torture around this time. More concerted research on the immediately preceding period is therefore needed if we are to establish with any certainty at what point music entered into this equation, and whether or not it did so along a direct path from sensory deprivation experiments or via other routes.

15 This leads us, however, to a more fundamental question: Why music? Some have argued, and some survivors of this form of torture have concurred, that at some point constant loud music stops being music and is simply noise. ${ }^{23}$ So why music? Why music instead of, 
or as well as, any number of other types of noise which are unbearable even for short periods, the types of noise that immediately trigger in us the reaction to cover our ears, the type of noise the very thought of which triggers a physical reaction in us? There are several obvious answers to the question, including the matter of convenience recordings may be available, a sound generator not; also, and as already mentioned, in some of these cases the primary use of music seems to have been to mask the evidence of torture, either acoustically or, vis-à-vis the jailers, psychologically. ${ }^{24}$ There is a pressing need for more research on this question, which would consider not only the more recent known cases - here, meaning from the 1970s onwards - but also older examples as well. What this essay will try to do is suggest some further hypotheses on the basis of existing research on related topics; my conclusion, in fact, will be that far from being surprising, the relationship between music and torture runs deep. It is therefore time to look at some other pathways, including some which will lead us to consider examples from much earlier eras as well.

\section{The military tradition pathway}

The use of music to accompany torture and corporal punishment, particularly in public and semi-public contexts, has origins that lie long before the twentieth century, as can be seen in the case of practices surrounding crime and punishment in Europe from the Middle Ages up to roughly the era of the Enlightenment. Drumming in particular was a frequent accompaniment to executions, for example, and it is likely that other forms of formal or informal music-making, or closely related activities, characterised this and similar public displays of punishment as well. As most famously discussed by Foucault, the path of criminal justice in general since the eighteenth century has moved away from the spectacular and towards the custodial. ${ }^{25}$ Yet even where it is forced into the criminal underground, torture often retains many aspects of these earlier and most public practices. Moreover, the trend towards prohibition took longer in some cases than in others, so that there may even be seamless connections between older and newer forms of punishment, particularly when we extend the discussion to other aspects of social organisation in the groups in question.

This is particularly the case when we look at the role of the military. In Britain, flogging was only fully outlawed in the military in the 1880s, a significant time after such punishment had been prohibited in civil criminal law. ${ }^{26}$ In many countries across Europe, there was a close and long-standing relationship between music and military discipline and punishment; in some cases, this even extended to military drummers being charged with inflicting corporal punishment on their comrades, as well as the playing of particular music at execution ceremonies and at what in English are still known as drumming-out ceremonies, when soldiers were dismissed from the army in disgrace. Drumming-out ceremonies cannot be classed as torture, but the ceremony as such and the role of music within it was designed to humiliate the disgraced soldier, with the playing of the "Rogue's March" and a not uncommon practice of his being led out of the barracks on a leash held by the smallest drummer-boy available. Such practices were fairly standard by no later than the second half of the eighteenth century. In such cases, music marks the importance of the occasion, not least since a vital function of these ceremonies was to serve as an example to others. I will discuss the use of music to humiliate, and as a symbol of dominant forces later. First, however, it is necessary to 
focus on larger issues of military organisation as these relate to developments in the security strategy of states from the later nineteenth century that would prove definitive and dreadful in the period to follow.

This development concerns a change in attitudes to civilian populations in a situation of war, a change that is interesting for historians of torture not least by virtue of the conclusions it draws about the nature and identity of enemies of the state, and how to deal with them. One of the most obvious testimonies to this change is the development, in several different contexts in the last years of the nineteenth century, of what were called concentration camps - a new way of organising and controlling "enemy" populations by collecting them all in one place; it was a practice that from the very start resulted in horrific mortality rates. Drawing on various sources including Isabel V. Hull's study of the German Imperial army up to and including the First World War, Jonathan Hyslop has argued that the emergence of more and more brutal practices against civilian populations in colonial regions at this time was tied inextricably to the increasing professionalisation of European armies in the same period. ${ }^{27}$ The first concentration camps developed as a direct result of scorched earth policies used by the Spanish in Cuba, the British against the Boers in South Africa, the Germans in South-West Africa, and the USA in the Philippines; guerrilla warfare tactics used by some in the populations affected often became the justification for attacks on the civilian population, who were cleared or concentrated into camps set up for that purpose. This development underlines an attempt on the part of the commanding officers concerned to draw a distinction between the "barbarian" types of warfare practiced by the other side, and the types of "civilized" warfare which - so they claimed - were the only real space in which the newly developed Hague conventions on the treatment of prisoners of war and civilians in wartime could be applied. There is an obvious and disturbing continuity between such rhetorical attempts to side-step international law and the rhetoric of the Bush administration in the US, which classed suspected terrorists as neither civilians nor prisoners of war for exactly this reason..$^{28}$ Such tactics are all too common: justifications for the use of torture are very often built on a similar logic, by arguing for an exceptional use of torture while upholding a general prohibition, ${ }^{29}$ and especially by classifying the victims as somehow outside of the normal social contract, either because they are hardened criminals, or simply because they are deemed dangerous on account of their national or ethnic background (the use of internment practices in wartime, like the early concentration camps, is one example of this; genocides, too, are often justified internally on these terms).

The importance of the development of camps such as these for the present discussion lies in the musical practices that, sometimes, went with them. Again this is an area where more historical and comparative work is needed, particularly to expand the existing basic data set that we have from studies into National Socialist concentration camps and the Soviet Gulag. Taking the former case as an example, however, it is striking how closely some of the official musical practices mirror their use in military contexts. Thus, we see what are to all intents and purposes military-style camp bands that play during role-call and while prisoners were marching to forced labour sites; ${ }^{30}$ the use of forced singing in some of these contexts may also be based in part on military traditions of singing as an essential part of training and drill, which became firmly established in the French and US armies during the First World War. ${ }^{31}$ Also analogous to earlier military traditions, camp bands too played during executions, and in the context of torture and other forms of corporal punishment. As Caplan and Wachsmann point out in their introduction to a 
recent overview of histories of the concentration camp system, camps of all types were incredibly prevalent in National Socialist Germany, and reflected central tenets of the NS ethos regarding the promotion of the collectivity over the individual. ${ }^{32} \mathrm{~A}$ connection back to systems of military organisation can be traced here as well, not least if we consider their significance as models for youth organisations in the late nineteenth and early twentieth centuries (and it is perhaps not irrelevant here that music played a key role in German youth organisations, a role that became even more exaggerated under National Socialism). Moreover, research has pointed to the more general role of military rolemodels in various aspects of social and political life, including in the structure and organisation of prisons, from the nineteenth century. ${ }^{33}$ And this is before we even consider the fact that so many of the examples we have of torture in the twentieth century, and the use of music in that context, come from military dictatorships, or situations where prison guards and interrogators are themselves members of the military.

An Amnesty International report on torture in Turkey published in 1985 provides other evidence of why this is relevant. The report indicates extensive use of forced singing mostly of marching songs - in prisons there. Generally, this happened in brief periods each day when prisoners were taken out into the open air, often immediately before they were subjected to violent physical beatings. The example below demonstrates that this type of "drill" was itself often used as a form of torture. Describing eleven months spent in Bağlar prison, one survivor said

The torture and violence here was even worse than in the police centre. Torture in the Baglar Prison became continuous and systematic about three or four months after the military takeover. Commandos took the prisoners out to the yard for air and made them go on all fours for hours on end and sing military marching songs. Then they beat and tortured them, again for long periods, with whatever they could lay their hands on: truncheons, sticks, iron rods ... After these "airings" many of the prisoners were carried into the dormitories unconscious. [...] If a prisoner did not shout or march well enough, did not sing the marches loudly enough or did not crawl properly, he was beaten right there and then in the presence of the other prisoners until he collapsed or fell unconscious. ${ }^{34}$

There are thus many plausible routes via which music could enter prison camps and other detention facilities as an extension of military traditions and practices. In the Gulag, in internment camps, and in the NS concentration camps, musical practices and activities were by no means limited to such contexts, and may not necessarily or initially have been motivated by the type of abject cruelty which often developed out of them. In such implicitly dehumanising contexts as these, however, - and indeed, in the context of armed conflict generally - any musical practice undergoes significant symbolic transformations which makes it amenable to use as a form of torture and CID punishment, as the next pathway will explore in more detail.

\section{The political communication pathway}

22 As just discussed, the use of torture in the twentieth century is very frequently linked to, or justified by, the perception of a threat to the state by political opponents, rebel groups, or terrorists. This is not infrequently extended to cover anyone ostensibly connected to these by virtue particularly of birth, heritage, nationality, ethnicity, or religion. It thus becomes clear that how people are identified, how they identify themselves, and how this 
identity is communicated, is as important with regard to the dynamics of torture as it is central to the larger-scale political conflicts that provide the context.

The relevance of this factor for the subject of music torture has to do with the musical repertoires involved. Discourses on music and torture, like discourses on music and violence generally, very often lapse into a neoplatonic focus on genres perceived to be particularly aggressive or violent because of their formal structure, their lyrical content, or both. (Or to put it more brutally and openly: they focus in the first instance on heavy metal and rap). A survey of known examples of the use of music in connection with torture and CID punishment points to discrepancies between this and the reality of how music (and which music) and violence are connected. Very often, the choice of music used in the context of torture is very pertinent indeed, not however because of particular abstract structural qualities, but for reasons related to what the music represents in the framework of the conflict in question. This is the reason why we find so many references to prisoners being forced to sing either their own songs or the songs of those who are maltreating them, ${ }^{35}$ and this is likewise the reason why the impact of this form of treatment may go beyond the most direct physical consequences associated with such practices. It is also likely the reason why survivors may remember and specifically refer to such incidences when recounting what has happened to them.

Such a use of music presupposes that the connections between the groups in question and the songs that they sing, make others sing, or are forced to sing, are both strong and wellknown. That what Ernst Klusen terms "group songs" are often associated with very strong emotional responses on the part of those singing them, is a mainstay of research into the social functions of song and singing, and is by no means limited to politicallydefined groups. ${ }^{36}$ The concerted use of song in political and social movements, and to help delineate political entities and institutions up to and including the nation state, has roots in the importance of song as a medium in pre-literate societies but also becomes more prominent and more potent since roughly the mid-eighteenth century, for various reasons related to developments in general communications, and the emergence of new forms of network and new types of political agency within those contexts. ${ }^{37}$ And the more important a song is for a politically-defined entity, the greater the possibility that it be used in contexts related to, and in some cases culminating in, torture.

There are two main reasons why this is the case. The first links in neatly with the previous section's discussion of the role of camps and other institutions and policies geared to controlling, or even eliminating, from a society elements within it deemed dangerous or useless. Re-education programmes are common in this context, and musical practices and activities often form a central component of these. In the case of both the NS concentration camps and the Soviet Gulag, music served several functions, including the attempt to portray the camps as spaces for cultural development rather than sites of maltreatment, illness, and death (this is another example of the way music can be used to try and mask evidence of torture, over and above masking the auditory evidence of victims' screams). The idea that music can be morally edifying may or may not be the initial or official reason for its integration into reeducation programmes; the actual manner of deployment of music in such contexts may however fly in the face of this. Systems of what is called reeducation are rarely limited to exposing prisoners to "improving" elements: they are about imposing state ideology and doctrine, and systematically breaking down opponents to the point at which they no longer pose any threat. Indeed, it was the potential of other methods, particularly drugs, to this end that 
led to experimentation on mind control on both sides of the Iron Curtain discussed previously. ${ }^{38}$ The use of music, and particularly forced singing, is often a less sophisticated version of the attempt to impose a state ideology on a resistant person, but in many cases a method used systematically and cruelly, as suggested by recent reports on the treatment of followers of Falun Gong in the People's Republic of China. ${ }^{39}$ The line between music and music torture in situations of "reeducation" can in some cases depend very much on the individual, with certain prisoners drawing strength from the opportunities they had to make or hear music, others however regarding this as a form of torture..$^{40}$ It should be noted, as well, that the situation of imprisonment in particular, or punishment and discipline more generally, ${ }^{41}$ mark off such programmes from the use of music as a tool of political education in other cases: as with music and torture generally, the impact cannot be separated from the context within which the practice occurs.

The second reason why forcing people to listen to or sing politically charged music lends itself to use as a method of torture becomes very obvious when we look at other examples as well, not least where the enforced music is related to the identity of the prisoners themselves rather than songs related to the dominant ideology in the case in question (the "reeducation" excuse simply does not work in these cases). Such uses bring us, almost in conclusion, to two very general observations on the nature of torture that explain in a much more general if deeply disturbing sense why there is, in fact, nothing at all surprising about the use of music in such situations.

\section{The humiliation pathway}

27 Human rights standards implicitly link torture with what it terms "cruel, inhuman and degrading treatment or punishment". What exactly is or is not covered by these latter terms is a subject of some debate, though generally speaking the range of situations and practices understood to fall into this category is expanding. ${ }^{42}$ Relevant for our own discussion is that while torture is generally considered to be a particularly grave form, torture is always cruel, inhuman, and degrading. Humiliation and mockery are almost invariably part of the picture.

This is also very true of the way music is used, or referenced, in this context. An interesting example of this is presented by some types of torture instruments that appear to have been widespread in the later Middle Ages, including what is sometimes called "the flute of shame": this is a metal device with a hoop that is placed round the neck of the victim, whose hands are inserted into an opening in a long piece of metal protruding from it, much in the manner in which a musician would hold a clarinet, oboe, or recorder. The curved "bell" at the end of the instrument is only decoration: the instrument is not hollow and no sound is omitted from it. The screws the instrument features are not ornamental, however; presumably, they would be gradually tightened until the victim's fingers were broken. ${ }^{43}$

Instruments such as the "flute of shame" and another in the general shape of a fiddle are far from music torture in the sense discussed here, yet are intrinsically connected to it by virtue of the common denominator of mockery and humiliation in the context of torture. Whether it takes the shape of a medieval flute or the form of a group of prisoners forced to sing and dance in front of their captors ${ }^{44}$ humiliation and cruelty are linked here in a way they are not, or not necessarily, in a number of other customs and practices in a much larger field of connections between music, discipline, and punishment in different 
societies and subsections of those societies; these include local and traditional systems of justice that use music and song in the context of shaming practices that are central to the way the society functions. ${ }^{45}$

These are only some of the ways in which music, mockery, and humiliation are connected across the world, including in formalised and informal uses of musical communication to mock and poke fun at others. One of the most obvious of these also points to just how fundamental this relationship may be. This is the musicalisation of taunts, jibes, and insults inflicted typically by children on other children, sometimes in forms that are playful and humorous, but also in the much more serious context of bullying. Research into both prosocial (e.g. playful) and antisocial (e.g. bullying) forms of teasing interaction amongst younger children points to the prevalence of emphasised and repetitive speech and "singsong" intonations in marking such interactions (something to which most of us, I suspect, can relate). Many of these are harmless, and in the views of some researchers may even have an important role to play in socialisation and language acquisition. ${ }^{46}$ Nevertheless, this connection and in particular the power relationships that develop in the non-harmless versions, particularly in the protracted and oftentimes psychologically devastating form of bullying, bring us to another and final pathway.

\section{The power performance pathway}

31 Torture is more than the infliction of extreme violence. The definitions favoured in international human rights law point to several other factors that can be regarded as crucial for an understanding of what torture actually is and how it functions. In addition to its relationship to cruel, inhuman and degrading punishment, take for example the fact that the definition given in the Convention Against Torture limits torture in the legal sense to acts perpetrated by agents of the state. ${ }^{47}$ This delimitation is by no means completely unproblematic, since it provides potential loopholes not least in situations where there are power struggles within a state and the torture is committed by parties not actually in power at the time concerned. Human rights campaigners know only too well, however, that the fact that torture is being carried out by an agent of the state is by no means irrelevant to the experience of the person being tortured. For if the state, with its monopoly on violence and its duty to protect me, treats me in this way, to whom can I turn? Who can save me? The fact that, as John Conroy points out, torturers are very rarely brought to justice (the state protects its own), only serves to underline this point. ${ }^{48}$

The relationship that exists between the torturer and the tortured, a relationship marked by the complete and absolute power of the former over the latter, is therefore one of the most definitive aspects of torture. And in a face-to-face situation such as this, how such relationships are formed, reformed, and expressed depends on a number of performative factors that give the cues to what is happening. A scene, or rather two linked scenes, from the award-winning documentary Songs of War may help clarify this. ${ }^{49}$ The film follows the American songwriter Christopher Cerf, most well-known for his creations for the American children's programme Sesame Street, as he attempts to understand how and why music - his own included - came to be used as an integral part of torture practices in US detention camps in the "War On Terror". In one scene, Cerf meets a former US interrogator, Mike, at his home and discusses with him the features of what has been euphemistically termed "enhanced interrogation", including subjection to music. Cerf then asks if he can experience something of what Mike is describing directly. In 
preparation for this role-play, Cerf is given a hood to wear, and Mike dons a mask. The scene cuts; in the new scene, we see the two men in the same setting as before, but their relationship to one another is utterly transformed. Testimony to this is not only the costumes they wear - the hood, the mask - but the speech patterns that guide their interaction. Mike speaks emphatically, and loudly: his voice has lost the constant modulations and subtle inflections of normal speech and has taken on the heightened and exaggerated tones of an expressive and angry outburst. Cerf may only speak when spoken to, and may only say what is expected of him. Their interplay, too, becomes heightened and exaggerated, as evidenced by the emphatic use of repetition:

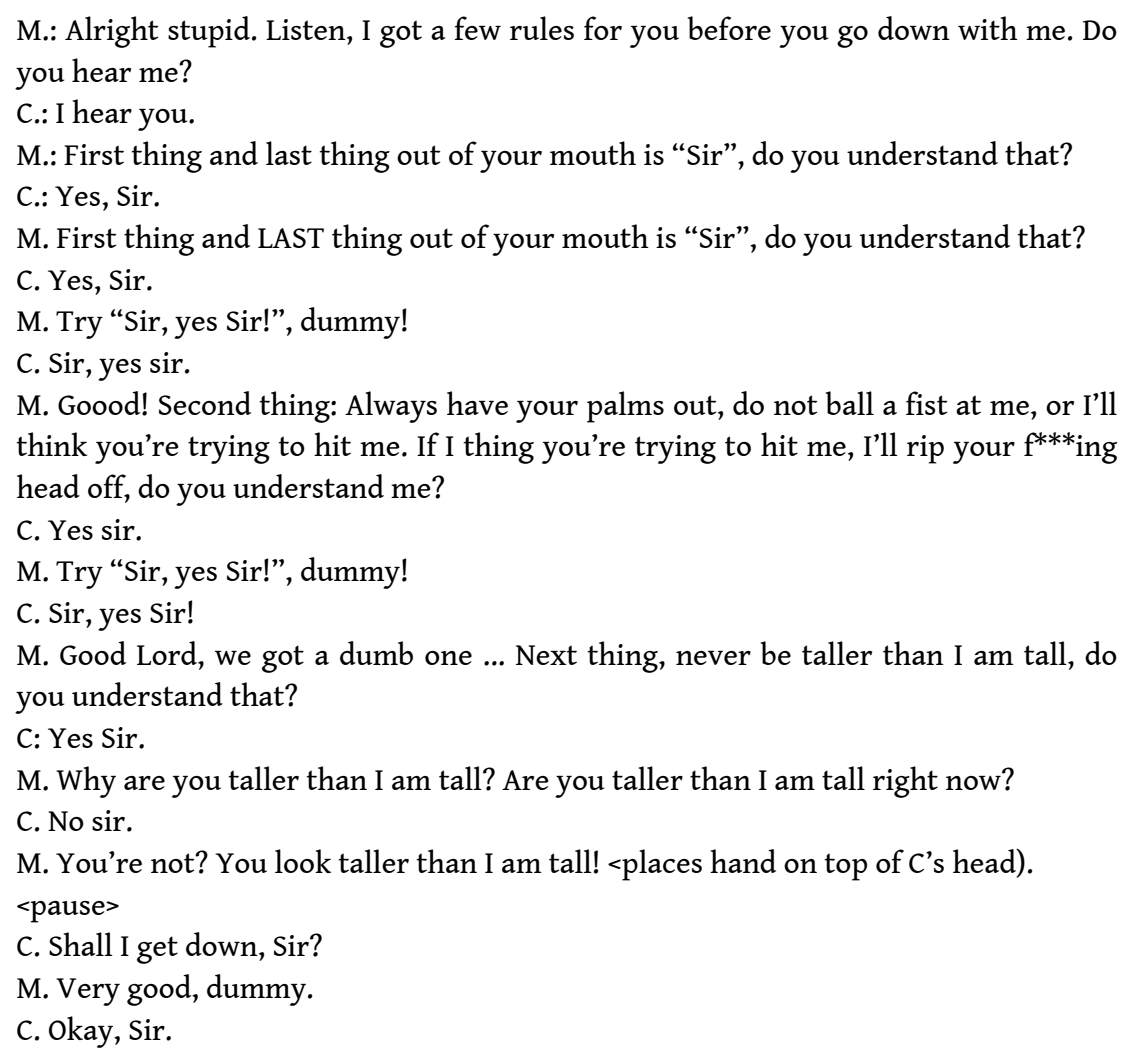

I have transcribed the dialogue here, but suggest readers consult the relevant passage in the film in order to follow essential aspects of the delivery. ${ }^{50}$ For it is exactly the combination of tone of voice, pitch, rhythm, repetition, and gesture - categories which can equally be applied to the analysis of musical communication - which are so telling in this exchange. A heightened and obviously performative interaction such as this demonstrates only too well that verbal and musical communication are often only different stages on a discontinuous but nevertheless connected spectrum. When talking about the typical characteristics of situations of teasing and bullying amongst children, the connection is very obvious; socio-linguistic work on this topic takes the use of repetition, singsong, and other types of what I would term "musical" communication to present cues as to what is going on in the situation. In other cases, the use of musical or musicalised communication in similar contexts of scapegoating and mocking similarly mark off what is happening and may also indicate the importance of the situation concerned. Where such situations become an entrenched part of a culture's system of justice ("culture" here can refer to such things as military culture, already discussed) the fact that acts of humiliation and even violence are embedded in the performance of a ritual, and thus legitimated by them, may make it easier for individuals to justify 
participation in acts which, in another context, would be subjected to very different social sanctions. That the performance discussed above is almost theatrical is thus by no means only because of the media representation of it: Mike is obviously acting out a role, but there is no reason to presume he would act it differently in a real situation of interrogation. The performance thus serves a dual function: to intimidate the prisoner, and to distance the interrogator psychologically from what he is doing.

Many readers may find interactions such as the one I have just described, and the preceding references to the singsong voice adopted by children in teasing, as too far removed from what they regard as music in the strict sense to be of relevance in an article discussing the use of music as torture. But even if we are to follow the centuriesold tradition of distinguishing, quite distinctively and emphatically, between different modes of human communication, expression, and interaction, rather than looking at their interconnections, it is not difficult to find other more obviously musical manifestations as well. Since structures of state-sanctioned power and dominance lie at the heart of the relationship between torturer and tortured, and since music often plays a key role in performing and constituting these structures both in the public eye and in personal experience, ${ }^{51}$ music and torture, it would seem, are not so far removed from each other after all.

The most important point here is a more general one. Music torture is perhaps unique amongst tortures in that it potentially brings benefits to the torturer simultaneously with pain and suffering for the prisoner. The word benefit seems a strange one to use in this case: its meaning is relative to the situation in which the torturer finds themselves, a situation in which they are to deliberately and remorselessly inflict excessive violence on a defenceless human being. They therefore have to overcome not only social and cultural, but possibly also more ingrained biological and emotional resistances to inflicting violence. ${ }^{52}$ Many of the ways in which music is used in the context of torture, including but not limited to its being played as a sort of soundtrack to violence, can be understood at least in part as a technique for facilitating or helping legitimise these acts. Generally speaking, there is a pressing need for more research into the use of music in the immediate preparation of violence, and at the moment of violence itself, in order to elaborate and test the fundamental theory governing this section - namely, that musical acts and practices in the broadest but also in the more narrow sense can become techniques used by humans to overcome any inhibitions they have about inflicting or condoning acts of great brutality..$^{53}$

\section{Conclusion: Pathways Out}

This article has consciously adopted a broad understanding of what constitutes music, musical communication, and a musical activity or practice, as an essential prerequisite to covering not only the many types of connection that exist between music and torture, but also as a way towards understanding the history and logic behind these connections. It has discussed at least two fundamental forms of music torture, namely those in which music is inflicted on the subject (by being played from recordings, or by musicians at the sites of torture and ill-treatment) and those in which the music is produced by the subject themselves (typically in the form of forced singing). The use of music in connection with torture must, I argue, be situated within a broader discussion not only of torture generally but also of the role of musical activities and practices in other contexts of 
disciplinary and punishment rituals, including but not limited to severe forms of corporal punishment. The potential of music to humiliate and mock detainees is suggested as one of the prime reasons for recourse to music, and thus emphasises that both the choice of music actually used, and its impact, cannot be limited to discussions of abstract structural qualities of the music; for the same reason, a conflation of music with other techniques of what is often termed sonic warfare is not sufficient if we want to understand more about the dynamics involved in this or any other form of musical communication. More research on all of these topics is necessary, however, particularly with regard to the longer history of this phenomenon, and with a view to establishing not only the effects of music torture on the victim, but also on the torturer.

It may be that the use of music in connection with torture has become particularly prominent and widespread in the period since roughly the mid-twentieth century, not just - this is important - because of developments in sound recording and reproduction technologies, but also, as explored above, because of many other developments in the kinds of wars we fight, and against whom, and because of changes in the way that we think about torture and the impact of international campaigns against torture. Linking the pathways above would likely be media and communication pathways not limited to direct example and army instruction manuals, and these are pathways which, if the metaphor be allowed, develop over the course of the twentieth century into information superhighways. ${ }^{54}$ By the same token, it is also clear that amongst the many uses, functions, and effects of music in connection with torture, the connection between music and all forms of cruel, inhuman, and degrading punishment is a more fundamental one. For all these reasons, there are as many potential pathways away from music torture as there are leading towards it: these might include establishing guidelines on the use of music in detention, adjustments to existing legislation and interpretations of that legislation, increased public knowledge, and improved human rights training for public officials and members of the security forces. Experienced campaigners will read this list, however, and conclude that ultimately all these paths lead to a much bigger Rome indeed. For the historical evidence suggests that as long as there is torture, there will be music used in the service of torture. The answer, then, is easy to say, but less simple to achieve: show me a world without music torture, and I will show you a world without torture.

\section{NOTES}

1. See particularly CUSICK, Suzanne G., “'You Are in a Place That is Out of This World': Music in the Detention Camps of the "Global War on Terror"', in Journal of the Society for American Music, 2/1, 2008, p. 1-26; WORTHINGTON, Andy, "A History of Music Torture in the War on Terror", available at http://www.andyworthington.co.uk/2008/12/15/a-history-of-music-torture-in-thewar-on-terror/, accessed 29 January 2012.

2. See particularly BRAUER, Juliane, Musik im Konzentrationslager Sachsenhausen, Berlin, Metropol, 2009; FACKLER, Guido, 'Des Lagers Stimme': Musik im KZ; Alltag und Häftlingskultur in den Konzentrationslagern 1933 bis 1936, Bremen, Temmen, 2000; FACKLER, Guido, "Music in the 
Concentration Camps 1933-1945" in Music and Politics 1/1, 2007, http://www.music.ucsb.edu/ projects/musicandpolitics/archive/2007-1/fackler.html, accessed 29 January 2013.

3. The examples I list below go back only (!) as far as the European Middle Ages, and most relate to a period from the later nineteenth century onwards. These are likely to be only the tip of the iceberg, however. As I have explored elsewhere, the connection between music, discipline, and punishment that has existed in military contexts from at least the late seventeenth century very probably has roots in much earlier practices, and may derive in part from Biblical sources. GRANT, M. J., "Music and Punishment in the British Army in the Eighteenth and Nineteenth Centuries", in the world of music (new series), vol. 2/1 (June 2013), special issue Music and Torture I Music and Punishment, guest editors M. J. Grant and Anna Papaeti, p. 9-30.

4. "Planton" was the name frequently given to this technique in Latin America at this time.

5. AMNESTY INTERNATIONAL, Affidavits on Torture in Uruguay. Statements Made Before Notary Public in Mexico City by Uruguayan Victims of Torture, London, Amnesty International, 1978. For ethical reasons I have chosen not to state the name of the person concerned.

6. UNITED NATIONAL HUMAN RIGHTS COMMITTEE, Raúl Cariboni v. Uruguay, Communication No. 159/1983, 27 October 1987, section 4. The UN committee decided in this case that the complainant had indeed been tortured, though they did not specify to which aspects of his treatment this judgment applied.

7. A survivor of torture in Guatemala who spoke to Amnesty International provides another example, probably dating from 1980: "I should also add that when the men were torturing someone, so that the soldiers should know absolutely nothing about what was going on inside, they would put tape-recorders on at full blast and make it sound as though they were singing. That's why when someone screams, when they are torturing him, these screams are simply not heard outside. They just hear the music they're playing". Interestingly, this comes in response to a question on how the survivor had known they were being held at an army installation; amongst other things, the survivor had heard "bugles and the shouting of the officers who were training the recruits". AMNESTY INTERNATIONAL, Guatemala: A Government Program of Political Murder, London, Amnesty International, 1981, p. 18.

Recognition that music could be used to this end is no new thing. In a nineteenth-century article in The Times relating to flogging in the British military an anti-flogging campaigner is reported to have claimed that the sound of loud drumming coming from an army barracks was designed to cover the screams of a man being flogged; this was disputed by some military figures. See GRANT, M. J., "Music and punishment in the British army in the eighteenth and nineteenth centuries, art. cit.

8. See e.g. CUSICK, Suzanne G., "'You Are in a Place That is Out of This World”, art. cit.

9. See PAPAETI, Anna, "Music, Torture, Testimony: Reopening the Case of the Greek Military Junta (1967-74)" in the world of music (new series), vol. 2/1, op. cit., p. 67-90.

10. "Musical qualities" could include, but are not limited to, melodic or emphasised tonal structure (including in speech), rhythm and repetition, coordinated movement, certain forms of gesture. It should go without saying that categories such as these are not necessary and sufficient conditions for music.

11. Discussions about what music "is" have a tendency to either be unwittingly specific or unnecessarily vague: steering a course between these two extremes is difficult. The reader might therefore want simply to hold on to the fact that in my view, reducing music to its sonic/acoustic dimension is an impoverishment that does not even begin to convey the complex mediations of all musical practice, and which may very often lead to aporias and contradictions in discussions about music. For an in-depth exploration of related issues see e.g. FUHRMANN, Wolfgang, “Towards a Theory of Socio-Musical Systems: Reflections on Niklas Luhmann's Challenge to Music Sociology", in Acta musicologica 83 (2011), p. 135-159, and FELD, Steven, "Communication, Music, and Speech about Music", in Yearbook for Traditional Music 16 (1984), p. 1-18. 
12. See for example FOLLMAR-OTTO, Petra, Die Nationale Stelle zur Verhütung von Folter fortentwickeln! Zur völkerrechtskonformen Ausgestaltung und Ausstattung, Deutsches Institut für Menschenrechte, 2013, available at http://www.institut-fuer-menschenrechte.de/uploads/ tx_commerce/

Policy_Paper_Die_Nationale_Stelle_zur_Verhuetung_von_Folter_fortentwickeln.pdf, accessed 8 July 2013, especially p. 6-10.

13. See “'Human Rights Have Made a Difference': An Interview with Manfred Nowak", in the world of music (new series), vol. 2/1, op. cit., p. 91-98, especially p. 96.

14. Histories of human rights often trace a trajectory back to, amongst other things, the American Bill of Rights, the French Declaration on the Rights of Man, and even to the English Magna Carta. The result is often a picture of human rights as a western development, indebted to the spirit of the Enlightenment. This is however not a fair representation of the history of human rights nor indeed of the demographies of the committee which drafted the Universal Declaration of Human Rights. See GLENDON, Mary Ann, A World Made New: Eleanor Roosevelt and the Universal Declaration of Human Rights, New York, Random House, 2001. According to Glendon, the central intellectual figures were the Chinese philosopher Peng-chun Chang, and Charles Malik, likewise a philosopher, from Lebanon; she also points to the contributions made by, amongst others, the Pulitzer-prizewinning Filipino journalist Carlos Romulo and Hansa Mehta from India, who was a strong proponent of effective recognition of the rights of women in the Declaration, and who also pushed for legal measures to ensure the Declaration could be enforced.

15. EINOLF, Christopher J., "The Fall and Rise of Torture: A Comparative and Historical Analysis", in Sociological Theory 25/2 (2007), p. 101-121.

16. McCOY, Alfred, A Question of Torture: CIA Interrogation From the Cold War to the War on Terror, New York, Metropolitan Books, 2006.

17. See for example SMITH, S. and LEWTY, W., "Perceptual Isolation Using a Silent Room", in The Lancet 2/7098 (1959), p. 342-345, who draw in their introduction on research conducted at McGill University and Princeton. Subjects in this experiment reported various disturbances including panic attacks, and in one case hallucinations; some subjects asked to leave the experiment after only six hours. I have included this reference due to the general availability of this article, published in one of the world's leading medical journals; references to further literature can be found in McCOY, op. cit. The Kubark Counterintelligence Interrogation manual, issued by the CIA in 1963 and now widely available online, refers directly to the results of experimental work on sensory deprivation conducted at a number of institutions. As the authors of the manual write, "a principle source of aid today is scientific findings. The intelligence service which is able to bring pertinent, modern knowledge to bear upon its problems enjoys a huge advantage over a service which conducts its clandestine business in eighteenth century fashion. It is true that American psychologists have devoted somewhat more attention to Communist interrogation techniques, particularly 'brainwashing', than to U.S. practices. Yet they have conducted scientific inquiries into many subjects that are closely related to interrogation: the effects of debility and isolation, the polygraph, reactions to pain and fear, hypnosis and heightened suggestibility, narcosis, etc. This work is of sufficient importance and relevance that it is no longer possible to discuss interrogation significantly without reference to the psychological research conducted in the past decade" (McCOY, op. cit., p. 2).

18. Cage related this anecdote several times, including in the essay "Experimental Music". CAGE, John, "Experimental Music", in Silence: Lecture and Writings, Middleton, Wesleyan University Press, 1961, p. 7-12. In their paper, Smith and Lewty explain their choice of a carefully insulated room since "'white-sound' generators, which blind out extraneous noises, are unsatisfactory because of the wide difference in frequencies which penetrate different establishments", SMITH and LEWTY, op. cit., p. 342. Their detailed description of the care needed to isolate the room used does however underline my general point about the impracticality of this in most settings. 
19. Noise, not music, was used in this case, and the literature on this topic generally presumes that music was not used in the case of interrogation and torture in Northern Ireland. However, another former prisoner whose sentence was only recently overturned, and who was not one of the fourteen at the centre of the case discussed here, has mentioned that music was played at the first interrogation centre he was brought to. This was in a school that had been adapted for the purpose: the music - played from a tape recorder between each interrogation cubicle - was apparently intended to make it impossible to hear what other detainees were saying during interrogation. See e.g. COBAIN, Iain, “Army 'waterboarding victim' who spent 17 years in jail is cleared of murder", in The Guardian, Thursday 21 June 2012, available at http:// www.guardian.co.uk/law/2012/jun/21/army-waterboarding-victim-cleared-murder, accessed 29 January 2013.

20. Lord PARKER of Waddington (Chair), Report of the Committee of Privy Counsellors Appointed to Consider Authorized Procedures for the Interrogation of Persons Suspected of Terrorism, London, Her Majesty's Stationery Office, 1972; see also NEWBERY, Samantha, "Intelligence and Controversial British Interrogation Techniques: The Northern Ireland Case, 1971-2", in Irish Studies in International Affairs 20/1 (2009), p. 103-119, and CONROY, John, Unspeakable Acts, Ordinary People: The Dynamics of Torture, New York, Alfred A. Knopf, 2000.

21. "Although the five techniques, as applied in combination, undoubtedly amounted to inhuman and degrading treatment, although their object was the extraction of confessions, the naming of others and/or information, and although they were used systematically, they did not occasion suffering of the particular intensity and cruelty implied by the word torture as so understood." EUROPEAN COURT OF HUMAN RIGHTS, Case of Ireland v. United Kingdom, Application No. 5310/71, Judgement, Strasbourg 18 January 1978, paragraph 167.

22. UN COMMITTEE AGAINST TORTURE, Concluding Observations of the Committee Against Torture: Israel. 05/09/1997. A/52/44, paras. 253-260. (Concluding Observations/Comments), paragraph 257.

23. See e.g. CUSICK, Suzanne G., "Musicology, Torture, Repair", in Radical Musicology 3 (2008), http://www.radical-musicology.org.uk, accessed 31 January 2013. Responses to music in detention and in the specific context of torture are highly individual (as, indeed, are responses to music generally). For this reason, it would be misguided to suggest any general theory of the conditions under which music would stop being perceived as such and instead heard simply as noise.

24. Many of these reports, including from Algeria and Paraguay as well as those already mentioned, state that the primary function of music was to drown out the sound of torture. But other reports show that the sound of music firstly did not always drown out the screams, and that secondly the music therefore only added to the horror for the victims. Thus, a survivor of torture in Turkey stated that "The screams which I heard coming from his room still ring in my ears. Screaming, crying, at the same time they play loud music. One can hear the torture screams of the others..."; another survivor interviewed in the same report takes a different view: "Sometimes the doors of the torture chambers were shut tightly and music was played very loudly in order to prevent the screams from being heard outside". AMNESTY INTERNATIONAL, Turkey: Testimony on Torture, London, Amnesty International, 1985, p. 20, 48. See also footnote 15, above.

25. FOUCAULT, Michel, Discipline and Punish: The Birth of the Prison transl. by Alan Sheridan, New York, Vintage Books, 1979.

26. It is almost certainly not irrelevant for this study, though I am unable to go into it here, that corporal punishment continues to be tolerated or even explicitly allowed in the majority of countries around the world against another and much larger social group, namely children.

27. HYSLOP, Jonathan, "The Invention of the Concentration Camp: Cuba, Southern Africa and the Philippines, 1896-1907", in South African Historical Journal, 63/2 (2011), p. 251-276. Exactly the same development - professionalisation in military structures and military organisation over the 
course of the nineteenth century - was in military historian John Keegan's analysis a major contributory factor in triggering the Great War; see KEEGAN, John, The First World War, London, Hutchinson, 1998.

28. Also, by holding prisoners at sites not territorially belonging to the US, it was believed US domestic law on the treatment of prisoners did not apply either.

29. See for example DERSHOWITZ, Alan, "Tortured Reasoning”, in LEVINSON, Sanford (ed.), Torture: A Collection, Oxford etc., Oxford University Press, 2004, p. 257-280; see also the response in the same volume given by SCARRY, Elaine, "Five Errors in the Reasoning of Alan Dershowitz", p. 281-290.

30. For a discussion of music and role-call and other aspects of musical life in the Gulag, see also KLAUSE, Inna, Musik und Musiker in sowjetischen Zwangsarbeitslagern der 1920er- bis 1950er-Jahre, doctoral dissertation, Hochschule für Musik, Theater und Medien Hannover, 2012.

31. See SWEENEY, Regina M., Singing Our Way to Victory: French Cultural Politics and the Great War, Middleton, Wesleyan University Press, 2001; and GIER, Christina, “'Dixieland in France': Deciding Musical Morality in American Military Culture during the First World War", in HANHEIDE, Stefan, HELMS, Dietrich, GLUNZ, Claudia and SCHNEIDER, Thomas (eds.), Musik bezieht Stellung. Funktionalisierungen der Musik im Ersten Weltkrieg, Göttingen, V\&R unipress, 2013, p. 161-174.

32. CAPLAN, Jane and WACHSMANN, Nikolaus, "Introduction", in CAPLAN, Jane and WACHSMANN, Nikolaus (eds.), Concentration Camps in Nazi Germany: The New Histories, London/New York, Routledge, 2010, p. 1-16.

33. See here e.g. HUGHES MYERLY, Scott, British Military Spectacle: From the Napoleonic Wars through the Crimea, Cambridge, Mass./London, Harvard University Press, 1996, particularly Chapter 9; also the description of daily prison routine given in the introduction to FOUCAULT, Michel, Discipline and Punish: The Birth of the Prison, transl. by Alan Sheridan, New York, Vintage Books, 1979.

34. AMNESTY INTERNATIONAL, Turkey: Testimony on Torture, op. cit., p. 36-37.

35. To take just one relatively well-known example, this practice was used extensively against Bosnian Muslim and Croat detainees, who were forced to sing Serb nationalist and Chetnik songs, in Serb camps during the war in Bosnia Herzegovina in 1992; see references in KLIP, André and SLUITER, Göran (eds), Annotated Leading Cases of International Criminal Tribunals: The International Criminal Tribunal for the Former Yugoslavia 2001-2002, vol. 8, Cambridge, Intersentia, 2005, p. 417, 601, 620, 655, 1052.

36. KLUSEN, Ernst, "Das Gruppenlied als Gegenstand" in Jahrbuch für Volksliedforschung, 12 (1967), p. 21-41; HEIMANN, Walter, Musikalische Interaktion: Grundzüge einer analytischen Theorie des elementar-rationalen musikalischen Handelns dargestellt am Beispiel Lied und Singen, Cologne, Musikverlag Gerig, 1982.

37. There is extensive literature on the role of music in social and political movements in the twentieth century in particular, and slightly less on the eighteenth and nineteenth centuries. Studies on music during the Reformation have also suggested that the Lutheran recourse to popular songs as a method of propaganda for the new faith had a considerable impact on the success of the Protestant cause; see e.g. OETTINGER, Rebecca Wagner, Music as Propaganda in the German Reformation, Aldershot, Ashgate, 2001. The case of Protestant church communities is an interesting one for demonstrating two related but distinctive factors relating to group song: firstly, before a period of widespread literacy and the spread of print media, songs fulfilled an important role in conveying information and moulding public opinion; secondly, the act not simply of listening to, but actively participating in singing in a group formed around an idea of religious, political, or national identity, would become more important with the emergence of new forms of public life and new forms of social networks from the early eighteenth century onwards. For a discussion of the connections between fraternal-type organisations in particular and the emergence of nationalism as reflected in group song, see GRANT, M. J., "Sung 
Communities", in BICHER, Karin, KIM, Jin-Ah and TOELLE, Jutta (eds.), Musiken: Festschrift für Christian Kaden, Berlin, Ries \& Erler, 2011, p. 81-93. See also Ron Eyerman and Andrew Jamison's excellent study focusing on the civil rights movement, which also points to the long-term cultural impact of protest music: EYERMAN, Ron and JAMISON, Andrew, Music and Social Movements: Mobilizing Tradition in the Twentieth Century, Cambridge, Cambridge University Press, 1998. Perhaps the most telling example of the role of song in political movements relates to the 1920s in Germany, when confrontations including street battles between National Socialist and Communist fractions often had a specifically musical element: in one case, Nazis marching through the left-wing area of Pankow in Berlin sang the workers' movement anthem The Internationale with adapted words, and were bombarded with flowerpots and other missiles. DITHMAR, Reinhard, “Das 'gestohlene' Lied. Adaptionen vom Liedgut der Arbeiterbewegung in NS-Liedern", in NIEDHART, Gottfried and BRODERICK, George (eds.), Lieder in Politik und Alltag des Nationalsozialismus, Frankfurt am Main, Peter Lang, 1999, p. 17-34.

38. MCCOY, Alfred, A Question of Torture: CIA Interrogation From the Cold War to the War on Terror, New York, Metropolitan Books, 2006.

39. Many of these reports, which can easily be found online, focus on "The Same Song", a Chinese pop song from the early 1990s that provides the title and title track to a music programme on China's main television channel CCTV. When it was reported that the song was to be performed live on stage at an event in Toronto in 2006, there were protests from many refugees who had been tortured for their affiliation to Falun Gong, and who said that the song was a central component in the brainwashing programmes to which they were subjected. I have been unable to find any studies collaborating or discussing this specific example.

40. As well as the literature on the NS concentration camps listed above, see e.g. KLAUSE, Inna, "Music in radio broadcasts in the Gulag", in GRANT, M. J. and STONE-DAVIS, Férdia J. (eds.), The Soundtrack of Conflict: The Role of Music in Radio Broadcasting in Wartime and in Conflict Situations, Hildesheim, Olms-Verlag, 2013, p. 13-23.

41. Here I am thinking particularly of what appears to be a widespread practice of using singing as a form of punishment in schools. I am unable to go into this subject in detail here, though it is worth pointing out that in terms of institutional environment, the imbalance in the power relationship between children and their teachers, and the difficulties children may face in responding to or complaining about acts of violence against them, the case of punishment in schools and in prisons may not be as far removed from each other as it may first appear. Similarly, although my focus in this article is on prisons and prison camps, the prevalence of treatment amounting to torture or CID punishment in other institutional environments including homes for older people and for the disabled - also needs to be considered in future work.

42. On the general question of definition, NOWAK, Manfred, Torture and other cruel, inhuman or degrading treatment:Report of the Special Rapporteur on the question of torture, UN Economic and Social Council Commission of Human Rights, sixty-second session, UN doc E/CN.4/2006/6, December 2006, section IV. Human rights advocates often now use the term CID punishment in connection with extremely poor conditions of detention in prison, e.g. severe overcrowding and lack of access to basic sanitation and health care.

43. Existing examples of this instrument are held in the Torture Museum in Amsterdam and in the Fortress Museum in Salzburg, amongst other places.

44. As for example in this report from the Philippines in the early 1980s: "The soldiers began drinking and interrogated the prisoners who were forced to sing while the soldiers used their heads as drums, beating them with two-inch square wooden battens until they bled. The prisoners were made to dance; ordered to remove their trousers; to masturbate and kiss and punch each other." AMNESTY INTERNATIONAL, Report of an Amnesty International Mission to the Republic of the Philippines, 11-28 November 1981, London, Amnesty International, 1982, p. 29. 
45. An example of this is offered by the so-called Hakkamat, female bards of the nomadic Baggara living for the most part in North and South Sudan. The various tasks fulfilled by the Hakkamat include literally singing the praises of, or alternatively deriding, men for their courage or cowardice. A negative decision by the Hakkamat as to a man's worthiness can resonate for generations and even lead to his being excluded from the community. The Hakkamat came to notoriety because of the apparent complicity of some Hakkamat in acts of genocide in Darfur; this one-sided appraisal of their role has however been criticised. Due not least to the conflict in the region, there is little recent in-depth work on the social functions, roles and positions of the Hakkamat. For a survey and contextualisation of available literature, including references to similar traditions in other societies, see JACOBS, Mareike, "Die Hakkamat und ihre soziale Rolle in der Gemeinschaft der Baggara", unpublished M. A. thesis, Georg-August-Universität Göttingen, 2011.

46. See e.g. MILLER, Peggy, "Teasing as language socialization and verbal play in a white working-class community”, in SCHIEFFELIN, Bambi. B. and OCHS, Elinor (eds.), Language socialisation across cultures, Cambridge, Cambridge University Press, 1986, p. 199-212; HARWOOD, Debra, BOSACKI, Sandra and BORCSOK, Kristina, “An investigation of young children's perceptions of teasing within peer relationships" in International Electronic Journal of Elementary Education, 2(2) (2010), p. 237-260.

47. "For the purposes of this Convention, the term 'torture' means any act by which severe pain or suffering, whether physical or mental, is intentionally inflicted on a person for such purposes as obtaining from him or a third person information or a confession, punishing him for an act he or a third person has committed or is suspected of having committed, intimidating or coercing him or a third person, or for any reason based on discrimination of any kind, when such pain or suffering is inflicted by or at the instigation of or with the consent or acquiescence of a public official or other person acting in an official capacity. It does not include pain or suffering arising only from, inherent in, or incidental to lawful sanctions." United Nations Convention against Torture and Other Cruel, Inhuman or Degrading Treatment or Punishment, Article 1/1. For a discussion of the UN definition and how it relates to recent US attempts to redefine torture, see NOWAK, Manfred, "What Practices Constitute Torture? US and UN Standards" in Human Rights Quarterly 28/4 (November 2006), p. 809-841.

48. CONROY, John, op. cit.

49. Songs of War, dir. Tristan Chytroschek, 2011.

50. The relevant passage (including the preceding discussion) is at around fifteen minutes into the film. At the time of writing the film can be viewed online in an English version at http:// www.aljazeera.com/programmes/aljazeeraworld/2012/05/201253072152430549.html and in a German version starting at http://www.youtube.com/watch?v=lnTn_3gWd_g, both accessed 31 January 2013.

51. See GRANT, M. J., "Sung Communities", in BICHER, Karin, KIM, Jin-Ah, and TOELLE, Jutta (eds.), Musiken: Festschrift für Christian Kaden, op. cit., p. 81-93.

52. This interpretation follows the work of COLLINS, Randall, Violence: A Microsociological Theory, Princeton, Princeton University Press, 2008.

53. Recognition of the potential benefits of music for management of the emotional impact of active combat lies at the heart of music's use in the modern military, particularly since the First World War: military music has a place comparable to the role offered by religious chaplains in the psychological services offered to serving soldiers in a number of armies. It is worth pointing out here that, far from being a simple case of "inspiration for combat" - to quote a chapter title given by Jonathan Pieslak in his, in this regard, sadly superficial work on American soldiers in Iraq - available evidence suggests that music is used to manage the fear associated with combat, to alleviate the stress associated with long periods of service in a combat zone, and to help deal with experience of being both a potential perpetrator and victim of violence. PIESLAK, Jonathan, 
Sound Targets: American Soldiers and Music in the Iraq War, Bloomington, Indiana University Press, 2009. For a different contemporary case study, based on the experience of German soldiers in Afghanistan from the perspective of a military musician who served there (the background situation being very different in that the troops in this case were there primarily to support and reestablish local security forces, rather than engage in active combat), see KRINER, Karl, "Alizée und der Fisch: Musikerfahrungen im Einsatzland Afghanistan", in SCHRAMM, Michael (ed.), Musik in Fremdwahrnehmung und Eigenbild, Bonn, Militärmusikdienst der Bundeswehr, 2009, p. 137-143. Studies of the Holocaust have pointed to a concerted promotion of music and other forms of entertainment in an attempt to counteract the psychological fall-out of executing men, women, and children by shooting; see e.g. BROWNING, Christopher, Ordinary Men: Reserve Police Battalion 101 and the "Final Solution" in Poland, New York, Harper Collins, 1992, especially p. 13-14, 112-113.

54. Hyslop, for example, points to the role of developments in the media in both triggering a debate on atrocities committed in the colonies but also in spreading information about newer techniques involved, such as the use of concentration camps. HYSLOP, Jonathan, art. cit; on the influence of media reports of British concentration camps in South Africa on early Soviet policy, see also HOLQUIST, Peter, "Violent Russia, Deadly Marxism? Russia in the Epoch of Violence, 1905-21" in Kritika: Explorations in Russian and Eurasian History 4/3 (Summer 2003), p. 627-652. Media developments would certainly accelerate the rate of exchange on military tactics which had, however, been going on for centuries.

\section{RÉSUMÉS}

Cet article s'attache à décrire le développement et la logique présidant à plusieurs usages de la musique en relation avec la torture, ainsi que d'autres formes de traitements cruels, inhumains et dégradants, suivant cinq directions distinctes, quoiqu'interconnectées: 1. la privation sensorielle, dérivant d'expérimentations en matière de torture psychologique menées durant la Guerre froide 2. la tradition militaire, inscrivant l'usage de la musique contre les prisonniers dans l'histoire plus longue de la musique comme discipline dans l'armée 3. la communication politique, relative au rôle central de la musique dans la formation et la communication d'identités politiques et, par conséquent, les conflits autour de ces identités 4 . l'humiliation, envisageant le contexte plus large de l'usage de la musique dans les pratiques de moquerie et d'humiliation informelles ou institutionnalisées 5 . la performance du pouvoir, réfléchissant à la relation entre le tortionnaire et sa victime. Les formes de torture musicale dont il est question dans cet article incluent l'exposition à de la musique diffusée fort, le chant forcé, et l'utilisation de la musique en rapport avec d'autres formes d'activité physique imposée.

This paper traces the development and logic of several uses of music in connection with torture and other forms of cruel, inhuman and degrading treatment along five distinct but interconnected pathways: i. the sensory deprivation pathway, deriving from experiments with psychological torture carried out during the Cold War period; ii. the military tradition pathway, situating the use of music against prisoners in the longer history of music and discipline in the military; iii. the political communication pathway, relating to the central role of musical practices in the formation and communication of political identities, and thus in conflicts surrounding those identities; iv. the humiliation pathway, looking at the larger context of the use 
of music in both informal and institutionalized practices of mockery and humiliation; v. the power performance pathway, reflecting on the relationship between the torturer and the tortured. Forms of music torture that are discussed in the article include exposure to loud music, forced singing, and the use of music in connection with other forms of enforced physical activity.

\section{INDEX}

Mots-clés : torture, torture musicale, traitements et sanctions inhumains et dégradants, chant forcé, droits humains

Keywords : torture, music torture, cruel, inhuman and degrading treatment or punishment, forced singing, human rights

\section{AUTEUR}

\section{MORAG JOSEPHINE GRANT}

Morag J. Grant (b. 1972 in Scotland) studied musicology in Glasgow, London and in Berlin, where she is based. From 2008-2014 she was junior professor of musicology at the University of Göttingen, where she founded and led the research group "Music, Conflict and the State". She has written extensively on music and armed conflict and on music in the context of punishment and torture. Her other research interests include the theory and aesthetics of new and experimental music, the social functions of song and singing, and the historical anthropology of music, particularly of Scotland and Britain. Her first book, Serial Music, Serial Aesthetics: Compositional Theory in Post-war Europe was published by Cambridge University Press in 2001; a second book, Auld Lang Syne: A Song and Its Culture, is awaiting publication. She is currently writing a third monograph on the social musicology of war (www.mjgrant.eu). 